\title{
The Relation of Public Expenditures with Economic Growth in OECD Countries
}

\author{
Şaban ERTEKIN* $\quad$ Şahin BULUT ${ }^{* *}$
}

\begin{abstract}
Many empirical studies have been conducted to analyse the relationship between public spending and economic growth. In the literature review for the analysis of this relationship, the studies are concentrated around Keynes and Wagner Hypothesis. Wagner argues that this relationship is from economic growth to public expenditures while Keynes argues that it is from public expenditures to economic growth. In this study, Keynes's hypothesis is examined through the use ofthe variables of economic growth, public expenditures, inflation and unemployment for some OECD member countries. The findings performed with the panel unit root and panel cointegration tests under the cross-sectional dependency in the analyses are as follows. The variables that make up the study are cointegrated among themselves. In the long-term analysis, a significant relationship was not obtained, which indicates that public expenditures and inflation affect economic growth. It is concluded that unemployment negatively affects economic growth. In the short run, it was found that both public expenditures and inflation positively affected economic growth, while unemployment had a negative effect. In the study, it is concluded that the Keynes Hypothesis is valid for DEU, CZE, GBR, HUN and $S V K$, but not valid for BEL, FIN and IRL.
\end{abstract}

Key Words: Public Expenditures, Economic Growth, Panel Data Analysis JEL Classification: H50, O47, C23

\section{OECD Ülkelerinde Ekonomik Büyüme ve Kamu Harcamaları Arasindaki İlişki}

\section{$\ddot{O} Z$}

Kamu harcamaları ile ekonomik büyüme arasındaki ilişkinin analizine dönük birçok ampirik çalışma yapılmıştır. Bu ilişkinin analizine dönük literatür incelemesinde ise, çalışmaların Keynes ve Wagner Hipotezi etrafinda yoğunlaştı̆̆ görülmektedir. Wagner bu iliş̧kiyi, ekonomik büyümeden kamu harcamalarına doğru olduğunu, Keynes ise kamu harcamalarından ekonomik büyümeye doğru olduğunu savunmaktadır. Bu çalışmada bazı OECD üyesi ülkeler için ekonomik büyüme, kamu harcamalarl, enflasyon ve işsizlik değişkenleri kullanılarak Keynes'in hipotezi araştırılmıştır. Yatay kesit bă̆ımlılı̆̆l altında panel birimkök ve panel eşbütünleşme testleri ile yapılan analizlerde elde edilen bulgular şu şekildedir. Çalışmayı oluşturan değişkenler aralarında eşbütünleşiktir. Uzun dönem analizinde kamu harcamalarl ve enflasyonun ekonomik büyümeyi etkilediğine dair anlamlı bir ilişki elde edilememiştir. İşsizliğin ise ekonomik büyümeyi negatif etkilediği sonucuna ulaşılmıştır. Kısa dönemde ise hem kamu harcamalarının hem de enflasyonun ekonomik büyümeyi pozitif etkilediği, işsizliğin ise negatif etkilediği bulgusu elde edilmiştir. Çalışmada, DEU, CZE, GBR, HUN ve SVK'da Keynes Hipotezinin geçerli olduğu, BEL, FIN ve IRL'da ise geçerli olmadiğı sonucu elde edilmiştir.

Anahtar Kelimeler: Kaти Harcamaları, Ekonomik Büyüme, Panel Veri Analizi.

JEL Sinıflandirmasi: H50, O40, C23

\footnotetext{
*Dr. Öğr. Üyesi, Aydın Adnan Menderes Üniversitesi, Aydın İktisat Fakültesi, Maliye Bölümü, saban.ertekin@adu.edu.tr, ORCID: 0000-0003-3438-3196

${ }^{* *}$ Doç. Dr., Aydın Adnan Menderes Üniversitesi, Aydın İktisat Fakültesi, Ekonomi ve Finans Bölümü, sbulut@adu.edu.tr, ORCID: 0000-0002-3462-6381
} 


\section{INTRODUCTION}

Public expenditures are defined as the expenditures made by authorized persons in order to meet the common needs arising from living together. It can also be expressed as the share of the public sector from the national income. Historically, these expenditures have followed a significant increase in parallel with the change and development in the duties and functions assigned to the public sector, and this increase has accelerated especially from the beginning of the twentieth century. The share of increasing public expenditures in GDP is one of the most important indicators of the size of the public sector in the national economy.

The reasons for the increase in public expenditures and its effects on the political and economic life has been among the topics discussed in the financial literature for a long time. The basic philosophies of classical financiers, who argue that the public sector should remain limited in economic life, are based on less public spending and less tax. It is argued that the natural balance in the economy should not be destroyed by public expenditures and taxes. According to this view, increasing public expenditures may negatively affect economic growth by creating an exclusion effect on private investments. However, proponents of Keynesian Economic Thought, who argue that the Great Depression was due to the lack of effective demand and that the total demand in the markets should be increased, claim that public expenditures should be increased. Although the increase in public expenditures has positive effects on the reconstruction of the economies that collapsed with the Great Depression and especially the Second World War, different economic results have emerged in the long term and the re-liberalization tendencies have gained importance especially after the 1970s. However, despite liberal discourses, the share of public expenditures in the national economy continues to increase in many countries depending on variables such as scientific and technological developments, defense expenditures, population growth and urbanization.

Increasing public expenditures with modern fiscal understanding are used as an important fiscal policy tool. However, its effects on macroeconomic variables, especially its relationship with economic growth, have been a subject of discussion. In the literature, there are two basic approaches that explain the causality relationship between public spending and economic growth. These are the views put forward by A. Wagner Hypothesis and Keynes. In both approaches, the causality relationship between public spending and economic growth and the direction of the relationship are analyzed. In this study, it will be analyzed whether there is a causality relationship between increasing public expenditures and economic growth. In the study, after examining the theoretical and conceptual framework of the relationship between public expenditures and economic growth, the relevant literature will be reviewed and econometric analysis will be made using selected OECD country data in the following sections. 


\section{THEORETICAL FRAMEWORK OF THE PUBLIC EXPENDITURE-GROWTH RELATIONSHIP}

The concept of economic growth refers to the increase in both total and per capita income and production amount in an economy (Ulusoy, 2016: 286). In most countries, economic growth and development, real increase in national income, is one of the most important economic targets. With the increasing importance of economic growth, there have been significant debates about the causality relationship between public spending and growth and the direction of the relationship. Whether public expenditures cause economic growth or economic growth causes an increase in public expenditures has been the subject of research in the literature. (Furat and Tuğlu, 2019: 2). However, no consensus has been reached in the theoretical and empirical studies.

The causality relationship between public expenditures and economic growth and the direction of this relationship are theoretically explained by the views of A. Wagner and J. M. Keynes (Şanlısoy and Sunal, 2016: 103). The hypotheses of Keynes and Wagner, representing different starting points, are the most discussed and tested hypotheses in the literature (Tümlüce and Yayla, 2017: 165). The first important studies on the increase of public expenditures were made by the German scientist A. Wagner at the end of the 19th century. Wagner, in his study on the course of public expenditures, determined that the increase rate of public expenditures is higher than the rate of increase in national income (Pehlivan, 2007: 68). According to Wagner, the increase in public expenditures depends on the increase in national income. One-unit increase in national income causes an increase of more than one unit in public expenditures (Demir and Balk1, 2019: 12). That is, the income elasticity of public expenditures is greater than one. This determination is referred to as "Wagner Law" or "Public Expenditures Increase Law" in the literature. Wagner argued that there is a one-way causal relationship from national income, that is, from economic growth to public expenditures, which means thatthere will be an increase in public expenditures at a rate higher than an increase in economic growth (Gövdeli, 2019: 997). In summary, it is argued that public expenditures are not a cause of economic growth, but a result, and that they increase faster than national income growth. In other words, economic growth expands the public sector by increasing public goods services (Biswal et al. 1999: 1283).

This hypothesis is based on increase in demand for public services such as education, health, social security, culture and environmentprovided by the public sector, which, therefore, brings about economic growth and prosperity. According to Wagner, with the economic growth, the socioeconomic structure will develop, as a result, education, health and other cultural services expected from the public sector will increase and this will result in an increase in public expenditures (Güder et al. 2016: 49). Classical and Neoclassical Liberal Economists, unlike the Keynesian view, argue that the direction of causality moves from economic growth to public spending, that is, public spending is a function of economic growth, and the Wagner hypothesis is consistent and valid (Nyasha and Odhiambo, 2019: 3). 
Drawing attention to increases in public expenditures caused by economic growth, Wagner's views are considered as the starting point of theoretical studies on the relationship between public expenditures and economic growth (Şanlisoy and Sunal, 206: 103). As a result, it is admitted that the relative share of public spending within the national income expands with economic growth (Magazzino, et al. 2015: $813)$.

Contrary to the Wagner hypothesis, in the Keynes hypothesis, it is argued that an increase in public expenditures, which is accepted as an external variable, will cause an increase in national income and therefore the causality is from public expenditures to economic growth (Y1ldiz and Sarısoy, 2012: 521). According to this hypothesis, public expenditures are an external policy tool that corrects shortterm cyclical fluctuations that affect economic growth. In other words, it is accepted that increasing public expenditures tend to cause an increase in total demand and a rapid economic growth occurs with this (Altıner, 2019: 852). Keynesian economists explain the effect of increase in public expenditures on national income with the multiplier mechanism. According to this approach, it is argued that public expenditures increase national income more than itself with the effect of the multiplier mechanism.

The concept of multiplier was first put forward by F. Kahn as the employment multiplier and later used by Keynes in the analysis of income generation (Çomaklı and Turan, 2016: 127). The multiplier is expressed as the coefficient showing the effect of one unit increase in autonomous expenditures made independently on national income. As a result, according to Wagner Law, public expenditures are an internal variable and the direction of causality is accepted from economic growth to public expenditure. However, it is thought that the increase in public expenditures, which is considered as an external variable in the Keynes Law, will cause an increase in national income and therefore the causality is from public expenditures to growth (Ar1soy, 2005: 64).

As a result, public spending is considered to be an internal factor or a consequence not a cause of economic growth according to Wagner's approach while it is accepted as an external factor that is considered as a tool of economic growth in Keynesian approach. Despite the differences in approaches, the correct diagnosis of the direction of causality between public spending and economic growth in policy-making in a country is of great importance. Accordingly, when Keynesian approach is adopted, public spending will become an important tool of economy policies. On the contrary, that is, in the economies in which Wagner hypothesis causality is valid, the importance of public spending as an important policy tool will diminish (Magazzino et al.2015: 813). According to endogenous growth model, in which it is argued that technological changes are determined internally within the internal dynamics of the economy itself, public policies and public spending will be a driving force for economic growth (Akbulut and Güran, 2015: 6). 


\section{LITERATURE REVIEW}

There are many empirical studies in the literature on the analysis of the relationship between public expenditures and economic growth. In the analysis made using the data of countries with different socioeconomic characteristics, it has been determined that the Keynesian Theory and Wagner Law were generally tested. Different results were obtained in the analysis of the relationship between public spending and economic growth and the direction of the relationship. In some of the studies, a one-way positive relationship was found between public expenditures and economic growth, while in others, a two-way causality relationship was found. In some studies, it was found that there was no causality relationship. The methods used in the analysis, variables and differences in the selected periods are considered to be important reasons for obtaining different results.

In the analysis results of Singh and Sahni B. S. (1984) based on the data of India's 1950-1981 period, no results supporting the Wagner hypothesis or the Keynesian theory were obtained. Similarly, in the work carried out by Olaoye, et al. (2019) to examine the causality relationship between public spending and economic growth in ECOWAS countries, it was concluded that there was no oneway or two-way causality. No causality relationship was found in the TodaYamamoto test conducted by Rauf et al. (2012) for the analysis of the relationship between Pakistan's public expenditures and national income for the period 19792009, either. In other words, it was concluded that the Wagner Hypothesis and Keynes Hypothesis were not valid, and that the main reason for the increase in public expenditures depended on factors such as defense expenditures, population growth, lacking sufficient levels of private sector and interest payments rather than growth. Similarly, Ajayi et al. (2016), in their analysis of the relationship between Nigeria's public spending and economic growth between 1985 and 2014, using the Toda-Yamamoto test, obtained the conclusion that Wagner Law and Keynesian Theory were not valid, that is, there was no causal relationship between public spending and economic growth. In the Granger test conducted by Ahmad and Ahmad (2005) for D-8 countries for the period of 1973-2002, it was concluded that there was no causal relationship between the increase in public expenditures and per capita income, and that there was only a causal relationship in Iran in the short term. In their Panel Data Analysis, based on data from 22 OECD countries for the period 1970-1995, Kneller et al (1999) concluded that increasing productive public spending or decreasing skewed taxes by $1 \%$ of GDP would provide a humble growth of from $0,1 \%$ to $0,2 \%$ annually in economic growth. These results are consistent with Barro (1990) model. The causal relationship of public spending on economic growth is closely concerned with the sort of public expenditures made (Ay, 2019: 129). In the analysis made by Devarajan et al. (1996) using different public expenditure components of developing countries, it was concluded that increase in current expenditures had a positive effect on economic growth, while increase in capital expenditures had a negative effect. Ghali (198) stated in his study on OECD countries that one of the important reasons of economic growth was the increase in public expenditures. Similarly, Loizides and Vamvoukas (2005) 
obtained the result that public expenditures caused an increase in national income in the short and long term, supporting the Keynesian theory, in the Granger causality tests conducted using the annual data of England, Greece and Ireland. In the Granger analysis of the existence and direction of the causality between public spending and economic growth in Nigeria by Udo and Effiong (2014), it was found that public expenditures had a direct effect on economic growth, which confirms the Keynesian approach. For a sustainable economic growth, the importance of public expenditures was emphasized. In the Johansen cointegration test conducted by Kimea and Kiangi (2018) to analyze the effects of public sector expenditures such as agriculture, education, transportation and communication on economic growth in Tanzania for the period 1968-2011, it was concluded that public expenditures do not have a long-term effect on economic growth. However, it was stated that expenditures other than agriculture, education and communication positively affected economic growth in the short term. In the study conducted by Dudzevičiūte et al (2018) on the analysis of the relationship between public expenditures and economic growth of eight EU countries, it was found that there was a significant relationship between public expenditures and economic growth. In their studies using data from 59 countries for the period 1990-2019, Ahuja and Pandit (2020) confirmed that there was a one-way causality relationship between public expenditures and GDP, which supports the Keynesian theory.

In their study covering 182 countries in a long period such as 1950-2004, Wu et al. (2010) concluded that public spending was a cause of economic growth, confirming the Wagner hypothesis. However, in the study, it was stated that public expenditures did not naturally affect economic growth due to the extremely limited public services such as energy supply, transportation and public health in very lowincome countries.

In the results of a study conducted by Pula and Elshani (2018) belonging to Kosovo covering the period 2004-2016, it was found that public expenditures were an important factor on economic growth, and economic growth had no effect on public expenditures in accordance with the results of the Wagner hypothesis. Additionaly, in causality tests for the 23 OECD countries by Lamartina, S., and Zaghini, A. (2011), and in the cointegration test conducted with the 1973-2012 data of India by Srinivasan, (2013); it was revealed that there was a one-way causality relationship from economic growth to public expenditures, which supports the Wagner law in the short and long term.

In the Panel Data Analysis regarding the validity of the Keynesian hypothesis by Lahirushan and Gunasekara (2015) for the Asian Countries for the period 1970-2013, it was found that public expenditures had a positive effect on economic growth. In addition, in the study, by confirming the Wagner hypothesis, it was concluded that economic growth had a positive effect on public spending. On the other hand, Lee, et al. (2019) analysed the relationship between public expenditures of Korea and China and economic growth. In the results of analysis, it was concluded that public expenditures had very little impact on growth because of China's socialist policies, tax incentives, subsidies and the active intervention of 
the public in the markets. However, in the same study, the flexibility of economic growth was found to be much higher due to the reduction of public interventions in the markets in accordance with IMF policies in Korea.

Ahuja et al. (2020), in the Panel Data Analysis they made using data from 59 developing countries for the period of 1990-2019, it was pointed out that there was a one-way causality relationship from economic growth to public expenditures, which confirms the Wagner hypothesis. In the analysis made by Jiranyakul (2020) using Thailand's quarterly data for the period 1997-2017 for the analysis of public expenditures and economic growth, it was stated that public expenditures had a positive effect on the total production level in the long term. The importance of increase in public expenditures was emphasized against the decreasing tendencies in the production level in the short term. In the analysis by Irandoust (2019) on the validity of the Wagner hypothesis for 12 countries, results that support the Wagner hypothesis in the long run were obtained in seven countries. Magazzino, et al. (2015) analyzed the causality relationship between economic development and public expenditures in EU countries and found that there was a close relation to the Wagner hypothesis rather than the Keynesian relationship between public expenditures and national income used in the model.

In Turkey, there are also similar studies to analyze the relationship between economic growth and public spending. In the Engle-Granger test (Bağdigen \& Çetintaş, 2004) for the validity of the Wagner Law for the period 1965-2000 in Turkey; it was found that there was no causality relationship between public expenditures and economic growth in the long run. Karhan (2018) analyzed the data of the BRICS countries and Turkey in the 1989-2017 period using VAR and VECM method. In the results of the analysis, a causality relationship from public expenditures to economic growth could not be found in the short term, while a causality relationship from economic growth to public expenditure was determined. In the same study, it was concluded that there was a two-way causality relationship between public expenditures and economic growth in the long run. Akbulut and Güran (2015) analysed the effect of transfer expenditures on economic growth in developing countries. In the analysis results using the data for the period 19902011, it was argued that the effect of public transfer expenditures on economic growth was positive and statistically significant in the long run, and transfer expenditures, which are used as a tool to solve problems such as income inequality and poverty, support economic growth in the long term.

In their study using quarter data for Turkey, Güder et al (2016) tested the relationship between economic growth and public spending with Granger causality tests. As a result of the Causality Analysis, it was revealed that there was a twoway causality relationship between public expenditures and economic growth, and the response created by the standard shocks given to both variables on the other was revealed by the effect-response analysis. Şanlısoy and Sunal (2016), likewise, examined the relationship between Turkey's public expenditure and economic growth for the period 1980 to 2010 with Wagner Law and Keynes hypothesis. In the results of the analysis, it was concluded that there was a causality relationship 
between public expenditures and growth in accordance with both Wagner Law and Keynes Hypothesis. Using annual data from 1985-2003, examining the validity of the Wagner Act in Turkey's economy, Iş1k and Alagöz (2005) used five different models. In the Johansen analysis, they concluded that economic growth had a positive effect on public expenditures, confirming the Wagner hypothesis, and that there was a two-way relationship between variables in other models. Ökde and Bülbül (2019) stated that there was a positive relationship between public expenditures and economic growth, a 1\% increase in public expenditures in the long term increases economic growth by $0.201 \%$ while Demirgil and Y1ldirım (2019) concluded that public spending positively affects economic growth in their analysis for EU countries.

In the modern world, the duties and functions attributed to public sector are increasing. Efficient use of scarce resources, ensuring economic development, establishing a fair distribution of income, justice, security, health and environmental protection are some of the duties assigned to the state. In the provision of these services, public sector expenditures are made in different amounts and composition in each country. Determining the impact of public expenditures on national income is important in determining whether scarce resources are used effectively and efficiently. This study aims to reach an opinion on whether public expenditures can increase national income.

\section{DATA AND EMPIRICAL RESULTS}

\section{A. Data}

In the study, the relationship between public expenditures and economic growth for 18 selected OECD member countries (Australia, Belgium, Czech Republic, Germany, Denmark, Spain, Finland, Great Britain, Hungary, Ireland, Italy, Netherlands, Norway, Poland, Portugal, Slovakia, Turkey, the United States) was carried out by using annual data for the period 2000-2018, cross-section dependence, heterogeneity and unit root tests, and then cointegration analysis was performed and the cointegration coefficients were estimated. Variables were obtained from the OECD website. Economic growth (Real GDP growth, annual\%), Gross national expenditure (GEX, \% of GDP), Inflation, consumer prices (CPI, annual\%) and Unemployment, total (UNP, \% of total labor force, modeled ILO estimate) variables were obtained from the WordBank website. The model for the data set of the study was created as follows:

$$
\begin{gathered}
G D P_{i t}=\propto_{0 i}+\alpha_{1 i} G E X_{i t}+\alpha_{2 i} C P I_{i t}+\alpha_{3 i} U N P_{i t}+\varepsilon_{i t} \\
(i=1,2,3, \ldots, N) ;(t=1,2,3, \ldots, T)
\end{gathered}
$$

In the model; GDP: real economic growth, GEX: public expenditures, CPI: inflation rate, UNP: unemployment rate.

In the panel data set, the cross-sections-dependency between countries (YKB) research was examined by Pesaran (2004) -CDLM (Cross-Section Dependence) and Breusch-Pagan (1980) tests. After determining the existence of CSD among countries, heterogeneity in the series was studied with the help of Pesaran and Yamagata (2008) Homogeneity Test. The unit root research in the series was examined with the second-generation unit root tests, Pesaran Cross- 
Sectionally Augmented Dickey Fuller (2007, CADF) and Hadri-Kurozumi (HK, 2012). Panel cointegration analysis was estimated with Westerlund DurbinHausman (W-D-H, 2008) test. Finally, the long and short-term relationship was estimated with the help of Autoregressive Distributed Lag (ARDL) Pesaran, Shin and Smith (1999) test.

\section{B. Empirical Results}

\section{Cross_section Depenedency and Slope Homogeneity}

At this stage, since there is a cross-sectional dependency (CSD) between countries $\mathrm{N}<\mathrm{T}(\mathrm{N}=18, \mathrm{~T}=19)$, Pesaran (2004), taking this situation into account, was studied with the help of CDLM and Breusch-Pagan (1980) test, and as a result of this analysis CSD was determined between the countries and the results are presented in Table 1.

Table 1. Cross Section Dependency Results

\begin{tabular}{|c|c|c|}
\hline YKB Test & Pesaran CDLM & Breusch-Pagan \\
\hline GDP & $7.732(0.000)$ & $288.249(0,000)$ \\
\hline GEX & $6.525(0,000)$ & $267.142(0.000)$ \\
\hline CPI & $3.165(0,001)$ & $208.373(0.002)$ \\
\hline UNP & $5.825(0.000)$ & $254.891(0.000)$ \\
\hline
\end{tabular}

Notes: The values shown in parentheses show the probability values of the test statistic. In the calculation, 1 was taken as the delay value.

After the determination of CSD among countries, the homogeneity research in the series was studied with the help of Pesaran and Yamagata (2008) Homogeneity Test and the findings obtained are given in Table 2.

Tablo 2. Homogenity Test Results

\begin{tabular}{|l|c|c|}
\hline \multicolumn{1}{|c|}{ Tests } & $\begin{array}{c}\text { Pesaran and Yamagata } \\
(\mathbf{2 0 0 8})\end{array}$ & $\begin{array}{c}\text { Statistics and probability } \\
\text { values }\end{array}$ \\
\hline Delta Tilda Stats. & 6.072 & 0.000 \\
\hline Adjusted Delta Tilda Stats. & 7.012 & 0.000 \\
\hline
\end{tabular}

In the analysis for homogeneity research, it was found that the series are heterogeneous. In other words, alpha and beta coefficients are different for each country that makes up the panel.

\section{Panel Unitroot Tests}

Therefore, Pesaran CADF and Hadri-Kurozumi (HK, 2012) tests, which are the second generation unit root tests that take into account heterogeneity, were used. The findings obtained as a result of the analysis are given in Table 3

Table 3. Pesaran (2006a)-CADF Unit Root Test Results

\begin{tabular}{|l|l|l|l|l|l|l|l|l|}
\hline \multirow{2}{*}{ Countries } & \multicolumn{2}{c|}{ GDP } & \multicolumn{2}{c|}{ GEX } & \multicolumn{2}{c|}{ CPI } & \multicolumn{3}{c|}{ UNP } \\
\cline { 2 - 9 } & t-ist. & $\mathrm{p}$ & $\mathrm{t}$-ist. & $\mathrm{p}$ & $\mathrm{t}$-ist. & $\mathrm{p}$ & $\mathrm{t}$-ist. & $\mathrm{p}$ \\
\hline BEL & $-0.57^{*}$ & 3 & $1.12^{*}$ & 2 & $-2.80^{*}$ & 3 & $-2.03^{*}$ & 2 \\
\hline AUS & $-2.64^{*}$ & 2 & $-1.37^{*}$ & 4 & $-2.25^{*}$ & 2 & $-2.73^{*}$ & 2 \\
\hline DNK & $-1.79^{*}$ & 3 & $2.66^{*}$ & 2 & $-1.49^{*}$ & 2 & $0.58^{*}$ & 4 \\
\hline DEU & $1.68^{*}$ & 3 & 3.82 & 2 & $-2.70^{*}$ & 2 & $-2.55^{*}$ & 2 \\
\hline FIN & $-2.27^{*}$ & 2 & $-0.46^{*}$ & 2 & $-1.19^{*}$ & 2 & $-1.10^{*}$ & 2 \\
\hline HUN & $-1.05^{*}$ & 2 & $-0.38^{*}$ & 2 & $-1.75^{*}$ & 2 & $-1.23^{*}$ & 2 \\
\hline CZE & $-1.73^{*}$ & 2 & $-1.35^{*}$ & 3 & $-2.46^{*}$ & 2 & $-1.35^{*}$ & 2 \\
\hline ITA & $-2.65^{*}$ & 3 & $-3.09^{*}$ & 2 & $-2.52^{*}$ & 2 & $-1.60^{*}$ & 3 \\
\hline IRL & $-1.79^{*}$ & 2 & $-2.45^{*}$ & 4 & $-3.46^{*}$ & 2 & $-0.69^{*}$ & 2 \\
\hline NOR & $-3.25^{*}$ & 2 & $-2.75^{*}$ & 2 & $-2.53^{*}$ & 2 & $-1.01^{*}$ & 3 \\
\hline
\end{tabular}


Şaban Ertekin \& Şahin Bulut / The Relation of Public Expenditures with Economic Growth in OECD Countries

\begin{tabular}{|l|l|l|l|l|l|l|l|l|}
\hline PRT & 3.57 & 2 & -4.20 & 2 & -3.88 & 2 & $-2.19^{*}$ & 2 \\
\hline POL & $-0.57^{*}$ & 3 & $-3.22^{*}$ & 2 & $-2.98^{*}$ & 2 & -3.73 & 4 \\
\hline ESP & $-3.13^{*}$ & 3 & $-2.33^{*}$ & 2 & -3.80 & 3 & $-1.14^{*}$ & 2 \\
\hline TUR & -4.06 & 2 & $-1.70^{*}$ & 2 & $-2.57^{*}$ & 2 & $-2.48^{*}$ & 2 \\
\hline GBR & $-1.07^{*}$ & 2 & $-1.21^{*}$ & 4 & $-1.82^{*}$ & 3 & $-0.65^{*}$ & 2 \\
\hline USA & $-2.22^{*}$ & 3 & $-2.76^{*}$ & 2 & $-2.57^{*}$ & 2 & $-1.21^{*}$ & 2 \\
\hline SVK & $-0.63^{*}$ & 2 & $-2.60^{*}$ & 3 & -3.56 & 2 & $-1.01^{*}$ & 4 \\
\hline NLD & $-0.65^{*}$ & 3 & $-1.88^{*}$ & 2 & $-1.08^{*}$ & 2 & $-2.97^{*}$ & 2 \\
\hline Critical Value & \multicolumn{2}{|c|}{-3.42} & \multicolumn{2}{|c|}{-3.42} & -3.42 & \multicolumn{2}{c|}{-3.42} \\
\hline
\end{tabular}

Notes: The unit root values calculated for the cross sections of the panel-countries are given in Table 3. The critical value required to compare these values is: -3.42 (intercept only) and it is taken from Pesaran's (2007: 275) study. *: unitroot.

Accordingly, it appears that some variables do not contain unit roots for some countries. The existence of the unit root indicates that the shocks coming to these countries in the series belonging to these countries are continuous, in other words, permanent. In addition, the findings obtained for the panel in general are presented in Table 4.

Tablo 4. Overall Results of Pesaran (2006)-CADF Unit Root Test Panel

\begin{tabular}{|c|r|r|r|r|r|r|r|r|}
\hline \multirow{2}{*}{ Tests } & \multicolumn{2}{|c|}{ GDP } & \multicolumn{2}{c|}{ GEX } & \multicolumn{2}{|c|}{ CPI } & \multicolumn{2}{|c|}{ UNP } \\
\cline { 2 - 9 } & EV & CV & EV & CV & EV & CV & EV & CV \\
\hline $\begin{array}{l}\text { CIPS Stat. Value for } \\
\text { the General Panel }\end{array}$ & $-1.96^{*}$ & -2.21 & $-2.06^{*}$ & -2.21 & -2.52 & -2.21 & $-1.62^{*}$ & -2.21 \\
\hline
\end{tabular}

Notes: EV: Estimation value, CV: Critical Value, Critical Values of the CIPS statistics values for the entire panel for the 5\% significance level *: unitroot, were taken from Pesaran (2007: 280). (Interceptly Only).

Accordingly, the entire panel contains unit root except for the CPI variable. In addition, according to the findings obtained from the Hadri-Kurozumi (2012) test used for unit root research of the data set, GDP and GEX series contain unit root, except for CPI and UNP series. The findings obtained are shown in Table 5.

Tablo 5. Hadri-Kurozumi (2012) Unit Root Test Results

\begin{tabular}{|c|c|c|c|c|}
\hline Variables & Definit & & $Z_{A}^{S P C}$ & $Z_{A}^{L A}$ \\
\hline \multirow{4}{*}{ GDP } & \multirow{2}{*}{ Constant } & statistics & -0.94 & -0.80 \\
\hline & & Pvalue & 0.82 & 0.78 \\
\hline & \multirow{2}{*}{ Constant and trend } & statistics & 0.50 & 2.65 \\
\hline & & Pvalue & 0.30 & $0.00 *$ \\
\hline \multirow{4}{*}{ GEX } & \multirow{2}{*}{ Constant } & statistics & -2.30 & -0.57 \\
\hline & & Pvalue & 0.98 & 0.71 \\
\hline & \multirow{2}{*}{ Constant and trend } & statistics & 1.06 & 1.82 \\
\hline & & $P$ value & 0.14 & $0.03 *$ \\
\hline \multirow{4}{*}{ CPI } & \multirow{2}{*}{ Constant } & statistics & 1.56 & -0.60 \\
\hline & & $P$ value & 0.94 & 0.72 \\
\hline & \multirow{2}{*}{ Constant and trend } & statistics & 2.71 & 3.44 \\
\hline & & $P$ value & $0.00 *$ & $0.00 *$ \\
\hline \multirow{4}{*}{ UNP } & \multirow{2}{*}{ Constant } & statistics & 18.07 & 6.75 \\
\hline & & $P$ value & $0.00^{*}$ & $0.00 *$ \\
\hline & \multirow{2}{*}{ Constant and trend } & statistics & 4.78 & 11.45 \\
\hline & & Pvalue & $0.00^{*}$ & $0.00 *$ \\
\hline
\end{tabular}

Notes: *: unitroot

At this stage, it was determined that the series contain unit root in their level values, and the degree of integrated of the series was determined as 1 . That is, the series difference is stationary and I (1) 


\section{Panel Cointegraiton Tests}

In a large number of recent studies, the Autoregressive Distributed Lag (ARDL) model has been extensively used to estimate trade balance equation (Bahmani-Oskooee and Brooks, 1999; Bahmani Oskooee and Kutan, 2009). For cointegration analysis, provided that the dependent variable is I (1) from the stationarities of the variables, the findings obtained in the cointegration analysis of Westerlund Durbin-Hausman (W-D-H, 2008), which allows the other variables to be I (1) and I (0) and takes into account the cross-sectional dependency,showed that the series forming the panel were cointegrated and the results are given in Table 6 .

Table 6. Westerlund Durbin-Hausman (2008) Cointegration Test Results,

Durbin-H Panel Cointegration Test Results

\begin{tabular}{|c|c|c|c|}
\hline Panel and Group Statistics & Statistical Value & Probability Value & Critical Value (\%5) \\
\hline Durbin-H Group Statistics & 3.162 & 0,001 & 1,645 \\
\hline Durbin-H Panel Statistics & 2.167 & 0,015 & 1,645 \\
\hline
\end{tabular}

According to the findings obtained as a result of the W-D-H cointegration test, it has been observed that there is a cointegration relationship throughout the country groups and the panel, as both group and panel statistics values are greater than the critical value. After determining that the variables are cointegrated, Panel Pesaran, et all. (1999) ARDL method was used to determine the long and short term relationships of the variables in the data set. This method allows the series to be the dependent variable I (1) and the others to be I (0) or I (1), taking into account the heterogeneity. The findings obtained are presented in Table 7.

\section{Panel Cointegraiton Vectors Tests}

Table 7. Results for PMG and MG Estimations

\begin{tabular}{|c|c|c|c|}
\hline $\begin{array}{c}\text { Dependent } \\
\text { variable: GDP }\end{array}$ & Pooled MGE Estimates & MGE Estimates & Hausman Test \\
\hline \multicolumn{4}{|c|}{ Long-Run Coefficients } \\
\hline GEX & 0.03 & 0.51 & $1.14^{* *}$ \\
\hline CPI & 0.06 & -0.18 & $0.47 * *$ \\
\hline UNP & $-0.17 * * *$ & 0.34 & $1.85^{* *}$ \\
\hline \multicolumn{4}{|c|}{ Error Correction Coefficients $\left.\left(\underline{E C T_{t-1}}\right)\right)$} \\
\hline Phi & $-0.93 *$ & $-1.05 * * *$ & \\
\hline \multicolumn{4}{|c|}{$\overline{\text { Short-run coefficients }}$} \\
\hline GEX & $0.03 * * *$ & 0.29 & \\
\hline CPI & $0.06 * * *$ & -0.22 & \\
\hline UNP & $-0.16^{* * *}$ & 0.23 & \\
\hline$\Delta \mathrm{tb}(-1)$ & 0.01 & 0.06 & \\
\hline$\Delta \mathrm{GEX}$ & 0.01 & -0.01 & \\
\hline$\Delta \mathrm{GEX}(-1)$ & -0.12 & -0.10 & \\
\hline$\Delta \mathrm{CPI}$ & 0.19 & $0.50 * * *$ & \\
\hline$\Delta \mathrm{CPI}(-1)$ & $-0.28 * * *$ & -0.18 & \\
\hline$\Delta \mathrm{UNP}$ & $-1.13 * * *$ & $-1.01 * *$ & \\
\hline$\Delta \mathrm{UNP}(-1)$ & 0.22 & -0.02 & \\
\hline Constant & 0.19 & -30.20 & \\
\hline
\end{tabular}

Notes: This selection can be made using standard information criteria such as the Akaike Information Criterion (AIC). The maximum number of lags for each variable is set at two, and optimal lag lengths are selected by the AIC. The MG estimates are used as initial estimates of the long-run parameters for the pooled maximum likelihood estimation. The PMG estimators are computed by "back-substitution" algorithm. ***, **, and * indicate 1, 5, and 10 percent levels of significance, respectively.

Since the data set in the study is known to be heterogeneous, there is no common beta coefficient for each country that creates the cross-sections. In the data 
set of the study and the relevant variables and estimators for the period 2000-2018, the countries where the Keynes hypothesis is valid according to the cointegration vectors belonging to each country forming the cross sections are as follows: DEU, HUN, CZE, GBR and SVK. On the other hand, the countries where the Keynesian hypothesis is not valid are BEL, FIN and IRL. Since the data set forming the panel is heterogeneous, the cointegration vectors obtained according to the groups are given in Table 8.

Table 8. Results for Group-Specific Estimates of the Long-Run Coefficients

\begin{tabular}{|c|c|c|c|c|c|c|c|c|c|c|c|c|c|c|c|c|}
\hline \multicolumn{9}{|c|}{ OLS VERSION } & \multicolumn{8}{|c|}{ PMLE VERSIO } \\
\hline & Phi & $t$ & $G E X$ & $t$ & CPI & $t$ & $U N P$ & $t$ & Phi & $t$ & $G E X$ & $t$ & CPI & $t$ & $U N P$ & $t$ \\
\hline EL & & $N A$ & & 99 & & & 0.71 & & -1.00 & $N A$ & .03 & -1.11 & & & & \\
\hline & & & & & & & & & & & & & & & & \\
\hline & & & & & & & & & & & & & & & & \\
\hline & & & & 2.17 & 0.01 & & & & ( & & & & & & $7 *$ & \\
\hline & $25 *$ & & $34 *$ & & -0. & & 0.54 & & -( & & 03 & & 0.06 & & & \\
\hline & & & & & & & & & & & & & & & & \\
\hline$\overline{\mathrm{ZE}}$ & $33 *$ & & & 84 & & & & & & & & & & & & 8.74 \\
\hline $\mathrm{A}$ & $40 *$ & & & .10 & -0.3 & & 0.2 & & - & & 0.03 & & 0.0 & & & 8.74 \\
\hline & & & & 81 & 0.89 & & & & $\left.\right|^{-1}$ & & & & 0 & & & 8.74 \\
\hline & & & 82 & .50 & & & 11 & & 1.00 & & 0.03 & & 0.06 & & & .74 \\
\hline & & & & & & & $-0.27 *$ & & $-1.29 *$ & & 0.03 & & & & & \\
\hline $\mathrm{OL}$ & & & & & & & 0.05 & & -1.00 & & 0.03 & & 0. & & & 8.74 \\
\hline & $-1.27 *$ & & -0.15 & & & & $-0.29 *$ & & $-1.02 *$ & & 0.03 & & 0.0 & & & 8.74 \\
\hline & & & & & & & & & & & & & 0.0 & & & \\
\hline & & & $2.13^{*}$ & & & & 0.15 & & -1.00 & $N A$ & 0.03 & & 0.06 & & & 8.74 \\
\hline & -1.00 & $N A$ & & -1.24 & & 0.47 & $-0.26^{*}$ & & -1.00 & & 0.03 & \begin{tabular}{|c|}
-1.11 \\
\end{tabular} & 0.06 & & $-0.17 *$ & 8.74 \\
\hline VK & $-1.45 *$ & 6.16 & $1.05 *$ & -3.08 & -0.97 & 1.5 & 0.12 & -0.49 & $-1.07 *$ & 4.8 & 0.03 & -1.11 & 0.06 & & & 8.74 \\
\hline JLD & -0.37 & 0.96 & -2.29 & 0.66 & 3.51 & -0.80 & -1.73 & 0.67 & $-0.67 *$ & 2.59 & 0.03 & -1.11 & 0.06 & -1.15 & $-0.17^{*}$ & 8.14 \\
\hline
\end{tabular}

Notes: *: significance,

Table 9. Results for Diagnostic Tests

\begin{tabular}{|c|c|c|c|c|c|c|c|c|}
\hline & \multicolumn{4}{|c|}{ PMGE } & \multicolumn{4}{|c|}{ MGE } \\
\hline & $x_{5 C}^{2}$ & $x_{H E}^{2}$ & $\bar{R}^{2}$ & $\mathbf{L L}$ & $x_{S C}^{2}$ & $X_{H E}^{2}$ & $\bar{R}^{2}$ & $\mathbf{L L}$ \\
\hline $\mathrm{BEL}$ & 2.90 & 0.03 & 0.82 & -14.78 & 52.47 & 0.03 & 0.55 & -22.41 \\
\hline AUS & 2.17 & 0.50 & 0.71 & -4.93 & 0.73 & 1.07 & 0.60 & -7.76 \\
\hline DNK & 0.28 & 0.24 & 0.85 & -15.31 & 3.50 & 0.02 & 0.41 & -26.68 \\
\hline $\mathrm{DEU}$ & 11.95 & 0.67 & 0.98 & -5.43 & 0.02 & 0.25 & 0.95 & -12.01 \\
\hline FIN & 1.98 & 0.57 & 0.97 & -11.02 & 0.04 & 0.87 & 0.77 & -27.73 \\
\hline HUN & 3.68 & 0.17 & 0.74 & -26.18 & 11.76 & 0.63 & 0.28 & -34.88 \\
\hline $\mathrm{CZE}$ & 0.03 & 0.43 & 0.89 & -17.30 & 16.37 & 0.17 & 0.46 & -31.15 \\
\hline ITA & 0.01 & 0.13 & 0.87 & -14.68 & 1.45 & 0.20 & 0.77 & -19.80 \\
\hline IRL & 11.12 & 0.04 & 0.62 & -40.53 & 8.38 & 0.00 & 0.45 & -43.64 \\
\hline NOR & 14.08 & 1.07 & 0.83 & -9.39 & 43.99 & 0.04 & -0.09 & -25.01 \\
\hline PRT & 1.71 & 0.29 & 0.82 & -20.95 & 2.13 & 0.00 & 0.80 & -21.72 \\
\hline POL & 2.17 & 0.03 & 0.75 & -20.03 & 35.23 & 0.68 & 0.41 & -27.63 \\
\hline ESP & 4.81 & 0.33 & 0.97 & 0.51 & 1.84 & 0.38 & 0.96 & -1.87 \\
\hline TUR & 3.72 & 1.20 & 0.83 & -31.00 & 0.24 & 1.69 & 0.76 & -34.02 \\
\hline GBR & 0.58 & 0.23 & 0.70 & -23.28 & 12.18 & 0.25 & 0.50 & -27.89 \\
\hline USA & 0.01 & 0.90 & 0.96 & 1.70 & 1.44 & 0.42 & 0.93 & -2.27 \\
\hline SVK & 2.01 & 1.23 & 0.79 & -28.67 & 0.36 & 3.31 & 0.25 & -39.43 \\
\hline NLD & 6.16 & 0.02 & 0.79 & -14.51 & 1.79 & 2.08 & 0.58 & -20.36 \\
\hline
\end{tabular}

Notes: $\chi_{S C}^{2}$ : Breusch-Godfrey serial correlation test statistic, $\chi_{H E}^{2}$ : White heteroscedasticity test statistic, $\bar{R}^{2}$ : Adjusted $R$ squared, LL: $\log$ Likelihood.

According to the cointegration coefficients of the series, public expenditures and inflation do not have a significant effect on economic growth in the long run. Unemployment, on the other hand, has a 0.17 unit reducing effect on 
economic growth in the long run. The error correction term is negative and statistically significant. This means that deviations in the short run will converge to equilibrium in the long run. The Hausman test strongly recommends PMG estimator. That is, the Haussman (1978) test strongly recommends choosing the PMG estimator against the MG estimator. In the short term, all variables are statistically significant. Accordingly, while public expenditures have a positive effect of 0.03 units and inflation has a positive effect of 0.06 units on economic growth; unemployment has a negative effect of 0.16 units.

\section{CONCLUSION}

There are two approaches that explain the relationship between public expenditure and economic growth in the economic literature: Keynes hypothesis and Wagner Hypothesis. Keynes stated that an increase in public expenditures will provide economic growth with a multiplier effect, that is, there is a positive relationship from public expenditures to economic growth. For this reason, Keynes advocated the use of public expenditures as an effective fiscal policy tool in issues such as ensuring economic growth and stability, establishing justice in income distribution, and ensuring economic development. On the contrary, Wagner argued that economic growth and development would cause a steady increase in public spending. According to this hypothesis, it has been determined that the rate of increase in public expenditures in industrialized countries will be higher than the rate of increase in economic growth. It is stated that this is due to the increase in demand for public goods and services together with industrialization and the increase and development in national income. However, there are different studies confirming both Wagner hypothesis and Keynes Hypothesis in theoretical and empirical studies. In this study, by using variables from different periods of some OECD countries, the relationship between public spending and growth is analyzed using different control variables.

In the study, the relationship between public expenditures and economic growth for 18 OECD member countries (Australia, Belgium, Czech Republic, Germany, Denmark, Spain, Finland, Great Britain, Hungary, Ireland, Italy, Netherlands, Norway, Poland, Portugal, Slovakia, Turkey, United States) is analyzed using annual data for the variables of economic growth, public expenditures, inflation and unemployment for the period 2000-2018. First, crosssection dependency, heterogeneity and unit root tests were carried out, and then cointegration analysis was performed and the cointegration coefficients were estimated. According to the general findings of the study, it is observed that there is cointegration between the series. In the long-term analysis, a significant relationship was not obtained, which indicates that public expenditures and inflation affect economic growth. It is concluded that unemployment negatively affects economic growth. In the short run, in accordance with the Keynesian hypothesis, it was found that both public expenditures and inflation positively affected economic growth, while unemployment affected it negatively.

According to the results of the panel unit root test under the cross-sectional dependency, according to the findings that some of the series contain unit root at 
the level and the others do not, using the Westerlund Durbin-Hausman test, which takes this situation into account, and the result is that the series are cointegrated. For the long and short run cointegration vectors of the series, cointegration vectors were calculated with the help of the Panel ARDL test, which also takes into account the stationary of the series at different degrees. According to the long-term results, under the countries in the data set of the study and the relevant variables and estimators for the period 2000-2018, according to the cointegration vectors belonging to each country forming the cross sections, the countries where the Keynes hypothesis is valid under are DEU, CZE, GBR, HUN and SVK. On the other hand, the countries where the Keynesian hypothesis is not valid are BEL, FIN and IRL. A significant relationship was not obtained for the other countries. These results are according to the OLS results suggested by the Hausman test.

As a result, the important reasons for the active role of the public sector to be in the economy are fairness in income distribution, efficiency in resource distribution, economic growth and development, and elimination of regional development differences. However, in this study, it has been noticed that countries' economies have different dynamics. The positive effect of public expenditures on economic growth and development may cause the public sector to grow, to become a clumsy structure, and to increase corruption and poverty in the long run. For this reason, policy makers have an important role in determining the expenditures that will positively affect economic growth and development without affecting the functioning of the free market. In particular, instead of unproductive expenditures that do not increase national income, spending that will positively affect the real economy such as education, health, social security expenditures, infrastructure and R\&D should be focused for the development of human capital.

\section{Araştırma ve Yayın Etiği Beyanı}

Makalenin tüm süreçlerinde Yönetim ve Ekonomi Dergisi'nin araştırma ve yayın etiği ilkelerine uygun olarak hareket edilmiştir.

\section{Yazarların Makaleye Katkı Oranları}

Makalenin tamamı Doç. Dr. Şahin Bulut ve Dr. Öğretim Üyesi Şaban Ertekin tarafından kaleme alınmıştır. Yazarlar çalışmaya eşit oranda katkı sağlamıştır

\section{Çıkar Beyanı}

Bu çalışmada herhangi bir potansiyel çıkar çatışması bulunmamaktadır.

\section{REFERENCES}

Ahmad, N. Ahmad, F. (2005). Does Government Size Matter? A Case Study Of D-8 Member Countries. Pakistan Economic and Social Review, XLIII, 199-212.

Ahuja, D. Pandit, D. (2020). Public Expenditure and Economic Growth: Evidence from the Developing Countries. FIIB Business Review, 9(3), 228-236.

Ajayi, M. A., Aluko, O. A. (2016). The Causality between Government Expenditure and Economic Growth in Nigeria: A Toda-Yamamoto Approach. Journal of Economics \& Business Research, 22(2). Pp: 77-90.

Akbulut, H., Güran, M. C. (2015). Gelişmekte Olan Ülkelerde Kamu Transfer Harcamaları ve Büyüme İlişkisi: Dinamik Panel Veri Yöntemi İle Uzun Dönem Analizi. Hacettepe Üniversitesi İ̈BF Dergisi, 33(1), 1-18. 
Arısoy, İ. (2005). Wagner ve Keynes hipotezleri çerçevesinde Türkiye'de kamu harcamaları ve ekonomik büyüme ilişkisi. Çukurova Üniversitesi Sosyal Bilimler Enstitüsü Dergisi, 14(2), 63-80.

Ay, H. (2019). Kamu Maliyesi 6. Bask1, Nobel Yayıncılık, Ankara.

Bagdigen, M. Cetintas, H. (2004). Causality Between Public Expenditure and Economic Growth: The Turkish Case. Journal of Economic and Social research, 6(1), 53-72.

Bahmani-Oskooee, M. and Brooks, T. J. (1999), Bilateral J-curve between US and her Trading Partners, Weltwirtschaftliches Archiv, 135: 156-65.

Bahmani-Oskooee, M. and Kutan, A. M. (2009), the J-curve in the Emerging Economies of Eastern Europe, Applied Economics, 41: 2523-32.

Biswal, B., Dhawan, U., Lee, H. Y. (1999). Testing Wagner Versus Keynes Using Disaggregated Public Expenditure Data for Canada. Applied Economics, 31(10), 1283-1291.

Breusch, T. S. and Pagan, A. R., (1980), The Lagrange Multiplier Test and Its Applications to Model Specification Tests in Econometrics, Review of Economic Studies, 47 (1): 239-53.

Çomaklı, Ş.E. ve Turan, D. (2016). Kamu Harcama Hukuku, Polis Akademisi Yayınlar, Ankara.

Demir, İ. C. Balkı, A., (2019). Türkiye'de Wagner Kanunu'nun Sınanması: 1960-2016 Dönemi Analizi, Vergi Raporu Dergisi, S:234(3), 11-27.

Demirgil, H. Yıldırım, S. (2019). Avrupa'da Kamu Harcamaları ve Ekonomik Büyüme Arasındaki İlişkinin Mekânsal Panel Veri Analizi İle İncelenmesi,. Avrasya Uluslararası Araştırmalar Dergisi, 7(18), 214-241.

Devarajan, S. Swaroop, V. Zou, H. F. (1996). The Composition of Public Expenditure and Economic Growth. Journal of Monetary Economics, 37(2), 313-344.

Dudzevičiūtè, G. Šimelytè, A. Liučvaitienè, A. (2018). Government Expenditure and Economicgrowth in the European Union countries. International Journal of Social Economics.

Fırat, E., Tuğlu, D. (2019). Finansal Kriz Dönemlerinde Kamu Harcamaları Ve Ekonomik Büyüme İlişkisi: 1998-2018 Türkiye örneği. Aksaray Üniversitesi İktisadi ve İdari Bilimler Fakültesi Dergisi, 11(3), 1-10.

Ghali, K. H. (1998). Government Size And Economic Growth: Evidence From A Multivariate Cointegration Analysis. Applied Economics, 31, 975-987.

Gövdeli, T. (2019). Kamu Harcamaları ve Ekonomik Büyüme: Türkiye'de Wagner Yasası ve Keynesyen Hipotezin Ampirik Analizi. Ataturk University Journal of Economics \& Administrative Sciences, 33(3).

Güder, F. Yücekaya, P. Şenyurt, A. (2016). Kamu Harcamaları ile Ekonomik Büyüme İlişkisi: Türkiye İçin Keynesyen Görüş Mü? Wagner Kanunu Mu Geçerli?(2006-2015 Dönemi). Çanakkale Onsekiz Mart Üniversitesi Uluslararası Sosyal Bilimler Dergisi, 1(1), 47-60.

Hadri, K. and Kurozumi E., (2012), "A simple panel stationarity test in the presence of serial correlation and a common factor", Econ. Lett., 115 (1) (2012), pp. 31-34

Hausman, J. A. (1978), Specification Tests in Econometrics, Econometrica, 43: 727-38

Irandoust, M. (2019). Wagner on Government Spending And National İncome: A New Look at on Old Relationship. Journal of Policy Modeling, 41(4), 636-646.

Jiranyakul, K. (2020). Government Expenditures and Economic Growth: A Cointegration Analysis for Thailand under the Floating Exchange Rate Regime. Available at SSRN 3597334.

Karhan, G. (2018). The Relationship Between Public Expenditures and Economic Growth: A Panel VAR approach. Cumhuriyet Üniversitesi İktisadi ve İdari Bilimler Dergisi, 19(2), 35-43.

Kimea, A. J. Kiangi, R. F. (2018). Economic Growth and Public Spending on Selected Sectors in Tanzania. International Journal, 6(1), 7-16.

Kneller, R., Bleaney, M. F., Gemmell, N. (1999). Fiscal Policy And Growth: Evidence From OECD Countries. Journal Of Public Economics, 74(2), 171-190.

Lahirushan, K. P. K. S., Gunasekara, W. G. V. (2015). The İmpact of Government Expenditure on Economic Growth: A Study of Asian Countries. International Journal of Social, Behavioural, Educational, Economic, Business and Industrial Engineering, 9(9), 29953003. 
Lamartina, S. Zaghini, A. (2011). Increasing Public Expenditure: Wagner's Law in OECD Countries. German Economic Review, 12(2), 149-164.

Lee, J. C., Won, Y. J., Jei, S. Y. (2019). Study of The Relationship Between Government Expenditures and Economic Growth For China and Korea. Sustainability, 11(22), 6344.

Loizides, J. Vamvoukas, G. (2005). Government Expenditure And Economic Growth: Evidence From Trivariate Causality Testing. Journal of Applied Economics, 8(1), 125-152.

Magazzino, C., Giolli, L., Mele, M. (2015). Wagner's Law and Peacock and Wiseman's Displacement Effect İn European Union Countries: A Panel Data Study. International Journal of Economics and Financial Issues, 5(3), 812-819.

Nihat, I. Alagöz, M. (2005). Kamu Harcamaları ve Büyüme Arasındaki İlişki. Erciyes Üniversitesi İktisadi ve İdari Bilimler Fakültesi Dergisi, (24), 63-75.

Nyasha, S. Odhiambo, N. M. (2019). Government Size And Economic Growth: A Review Of İnternational Literature. SAGE Open, 9(3), 2158244019877200.

Olaoye, O. O., Orisadare, M., Okorie, U. U. (2019). Government Expenditure and Economic Growth Nexus in ECOWAS Countries: A Panel VAR Approach. Journal of Economic and Administrative Sciences. Vol. 36 No. 3, pp. 204-225

Ökde, B. Bülbül, D. (2019). Kamu Harcamaları ve Ekonomik Büyüme Arasındaki İlişki: G7 Ülkeleri İçin Panel Veri Analizi, Electronic Journal of Social Sciences, 18(69).

Pehlivan, O. (2007). Kamu Maliyesi, Derya Kitabevi, Trabzon.

Pesaran, M.H. (2004). "General Diagnostic Tests for Cross Section Dependence in Panels", Cambridge Working Papers in Economics, 435.

Pesaran, M. H., Shin, Y. and Smith, R. J. (1999), Pooled Mean Group Estimation of Dynamic Heterogeneous Panels, Journal of the American Statistical Association, 94: 621-34.

Pesaran, M. H., (2006), Estimation and Inference in Large Heterogeneous Panels with a Multifactor Error Structure, Econometrica, 74 (4): 967-1012.

Pesaran, M. Hashem (2007). "A Simple Panel Unit Root Test in the Presence of Cross-Section Dependence". Journal of Applied Econometrics, 22, 265-312.

Pesaran, M.H. ve Yamagata, T., (2008), Testing Slope Homogeneity in Large Panels, Journal of Econometrics, 142 (1), 50-93

Pesaran, M.H., Ullah, A. and Yamagata, T., (2008). “A Bias-Adjusted LM Test of Error Cross-Section Independence”, Econometrics Journal 11(1): 105-127.

Pula, L., Elshani, A. (2018). The Relationship Between Public Expenditure and Economic Growth in Kosovo: Findings From A Johansen Co-İntegrated Test and A Granger Causality Test. Ekonomika (Economics), 97(1), 47-62.

Rauf, A. Qayum, A. Zaman, K. U. (2012). Relationship Between Public Expenditure and National İncome: An Empirical İnvestigation of Wagner's Law in Case of Pakistan. Academic Research International, 2(2), 533.

Singh, B. Sahni, B. S. (1984). Causality Between Public Expenditure And National İncome. The Review of Economics and Statistics, 664, 630-644.

Srinivasan, P. (2013). Causality Between Public Expenditure and Economic Growth: The Indian Case. International Journal of Economics and Management, 7, 335-347

Şanlısoy, S. Sunal, O. (2016). Kamu Harcamaları-Ekonomik Büyüme İlişkisi: Türkiye Örneği. Gümüşhane Üniversitesi Sosyal Bilimler Enstitüsü Elektronik Dergisi, 7(17), 102-122.

Udo, A. Effiong, C. (2014). Economic Growth And Wagner's Hypothesis: The Nigerian Experience. Journal of Economics and Sustainable Development, 5(16), 41-48.

Ulusoy, A. (2016). Maliye Politikası, Umuttepe Yayınları, Kocaeli.

Westerlund, Joakim, (2008), Panel Cointegration Tests of the Fisher Effect, Journal of Applied Econometrics, 23(2): 193-233.

World Bank (2020). "World Development Indicators", https://databank.worldbank.org/indicator/NY.GDP.MKTP.KD.ZG/1ff4a498/PopularIndic ators\# (Erişim Tarihi:17.10.2020).

Wu, S. Y. Tang, J. H., Lin, E. S. (2010). The İmpact of Government Expenditure on Economic Growth: How Sensitive to The Level Of Development?. Journal of Policy Modeling, 32(6), 804-817. 
Yayla, N. Tülümce, S. Y. (2017). Türkiye'de Kamu Harcamalarının Bileşenleri ve Ekonomik Büyüme İlişkisi: Wagner Ya Da Keynes?. Social Sciences, 12(4), 163-184.

Yıldız, F. Sarısoy, S. (2015). OECD Ülkelerinde Kamu Harcamaları ve Ekonomik Büyüme İlişkisi Üzerine Amprik Bir Çalışma. İktisadi ve İdari Bilimler Dergisi; Cilt 33, Sayı 2 (2012); 517 540. 